\title{
Top predators affect the composition of naive protist communities, but only in their early-successional stage
}

\author{
Axel Zander $^{1} \cdot$ Dominique Gravel $^{2} \cdot$ Louis-Félix Bersier $^{1} \cdot$ Sarah M. Gray $^{1}$
}

\begin{abstract}
Introduced top predators have the potential to disrupt community dynamics when prey species are naive to predation. The impact of introduced predators may also vary depending on the stage of community development. Early-succession communities are likely to have small-bodied and fast-growing species, but are not necessarily good at defending against predators. In contrast, late-succession communities are typically composed of larger-bodied species that are more predator resistant relative to small-bodied species. Yet, these aspects are greatly neglected in invasion studies. We therefore tested the effect of top predator presence on early- and late-succession communities that were either naive or non-naive to top predators. We used the aquatic community held within the leaves of Sarracenia purpurea. In North America, communities have experienced the $S$. purpurea top predator and are therefore nonnaive. In Europe, this predator is not present and its niche has not been filled, making these communities top-predator naive. We collected early- and late-succession communities
\end{abstract}

L.-F. Bersier and S. M. Gray: senior authorship.

Electronic supplementary material available

Axel Zander

axel.zander@unifr.ch

1 Unit of Ecology and Evolution, Department of Biology, University of Fribourg, Chemin du Musée 10, 1700 Fribourg, Switzerland

2 Département de biologie, chimie et géographie, Université du Québec à Rimouski, 300 Allée des Ursulines, Rimouski, QC G5L 3A1, Canada from two non-naive and two naive sites, which are climatically similar. We then conducted a common-garden experiment, with and without the presence of the top predator, in which we recorded changes in community composition, body size spectra, bacterial density, and respiration. We found that the top predator had no statistical effect on global measures of community structure and functioning. However, it significantly altered protist composition, but only in naive, early-succession communities, highlighting that the state of community development is important for understanding the impact of invasion.

Keywords Aquatic top predators - Naive prey · Succession · Invasion · Sarracenia purpurea

\section{Introduction}

Top predators are known to have major impacts on community structure in both aquatic and terrestrial systems (Gurevitch and Padilla 2004; Salo et al. 2007; Estes et al. 2011) and are important for community dynamics (e.g., Hunter and Price 1992; Kneitel and Miller 2002) and ecosystem functioning (Hairston et al. 1960; Carpenter et al. 1985). Recently, with the increase in the movement of species around the world due to human transport, predators are being introduced to novel communities and are having a major effect (Gurevitch and Padilla 2004; Salo et al. 2007). This phenomenon has opened a new research path that tests whether novel predators have larger effects on invaded communities than on their native community. This prediction is based on the absence of shared evolutionary history between the predator and prey in the invaded communities [naive prey hypothesis (Elton 1958; Diamond and Case 1986; Cox and Lima 2006; Freeman and Byers 2006)] and 
support for this hypothesis has been demonstrated recently by Paolucci et al. (2013). In Paolucci et al.'s (2013) metaanalysis, alien predators had a 2.4 times stronger negative effect on prey compared to native predators, with similar effect sizes for herbivores and carnivores and for terrestrial and aquatic ecosystems (Paolucci et al. 2013; but see also Salo et al. 2007). The strong effects found by Paolucci et al. (2013) are illustrated by the well-known introduction of the brown tree snake (Boiga irregularis) to Guam (Savidge 1984, 1987; Wiles et al. 2003; Sih et al. 2010), where $90 \%$ of the local bird species were exterminated. Of the six bird species that were least affected by the snake, four were introduced to Guam and had co-evolved with snake predators, and the other two occupy different habitats than the snake (Wiles et al. 2003).

The differential effect of introduced predators on naive vs. non-naive (i.e., co-evolved with a predator type similar to the introduced predator) communities has also been found in Australia, where introduced predators have a larger effect on communities than native predators (Salo et al. 2007). For island communities in general, the effects of novel predators are found to be particularly severe compared to on the mainland (Courchamp et al. 2003, but see Paolucci et al. 2013). This island concept can also apply to enclosed freshwater ecosystems, which are typically limited in size and isolated from other aquatic habitats. It is of little surprise then that examples exist where introduced aquatic predators strongly impact local communities [e.g., the Nile perch Lates spp. (Goldschmidt et al. 1993), the rainbow trout Oncorhynchus mykiss (Baxter et al. 2004), or the zander Sander lucioperca (Manchester and Bullock 2000)].

Despite the potentially large impact of novel predators on naive communities, few studies have addressed this question (Dickman 1996; Bruno et al. 2005; Cox and Lima 2006; Rodriguez 2006). Lowry et al. (2013) showed that less than $10 \%$ of the research conducted on invasive species has focused on top predator invaders, and a majority of this research was conducted in terrestrial systems. Additionally, most of these studies used field observations and not experiments. Consequently, there is a major need to experimentally test the effect that top predators have on naive prey communities. This question is particularly relevant in freshwater systems (e.g., lakes, ponds), because barriers for the expansion of predators (e.g., waterfalls, terrestrial environment) occur more often in such systems and increase the likelihood that if novel predators are introduced, they will encounter naive prey communities (Moyle 1986; Cox and Lima 2006). Further, these systems are usually top-down controlled (e.g., Shurin et al. 2002), thus an invasion by a top predator is likely to have strong negative effects.
Aside from the naivety status, another aspect known to affect invasion success of a species is the successional stage of the host community (Connell and Slatyer 1977; Fabian et al. 2012; Oakley and Knox 2013). The organization of early-succession communities is difficult to predict due to idiosyncratic immigration events, but they are typically composed of small-bodied species with high dispersal and reproduction abilities (e.g., Odum 1969; del Moral and Wood 1993; Foster and Tilman 2000; Catford et al. 2012). Community structure changes through time because of the subsequent immigration of species with lower dispersal potential (Lortie et al. 2004), the addition of multiple trophic levels, and the biotic interactions within trophic levels (e.g., Odum 1969; Belyea and Lancaster 1999). This could lead to more predictable and stable communities, typical of late-succession (Clements 1916; but see Gleason 1926). Such communities are characterized by the presence of competitive large-bodied species (Sommer et al. 1986) that allocate more energy to exploit resources and for defense (Pianka 1970; Foster and Tilman 2000; Pomati et al. 2013). The transition between these states can be explained by the displacement of small-bodied species by larger and more competitive ones (e.g., Wootton 1993; Foster and Tilman 2000), and the preferential predation of abundant small-bodied species during earlysuccession (Sousa 1979; Wootton 1993; Hansson et al. 1998). Non-equilibrium dynamics are typically prevalent in early-succession compared to late-succession communities (Hutchinson 1961; Connell and Slatyer 1977; Rees et al. 2001) because of higher reproductive rates of early-succession species (Jiang et al. 2011) and stronger top-down control by predators (e.g., Schmitz et al. 2006). For predatory invaders, it is expected that they should benefit from the prevalence of small and fast-growing species that allocate more energy to reproductive output (offspring that are themselves easy prey) than to defense mechanisms (Pianka 1970; Walls et al. 1990). Thus, we hypothesize the impact of predation to be stronger in early- than in late-succession communities. In all, to understand the factors affecting the impact of an invasive predator, it is important to consider the possible combined effects between naivety status and successional stage of a community.

One reason for the lack of experiments addressing the effect of top predator invasion is that large-scale communities are complex, making the control of confounding factors challenging. Model systems of microorganisms can provide the tractability and high statistical power that is often difficult to obtain in larger-scale systems (Srivastava et al. 2004). The rainwater-filled leaves of Sarracenia purpurea is one such model system for aquatic communities (e.g., Miller and Kneitel 2005). This system shows the typical dynamics of larger aquatic food webs, but on small spatial and short time scales (e.g., Addicott 1974; Heard 
1994; Kneitel and Miller 2002; Gotelli and Ellison 2006; Gray et al. 2006; Hoekman 2007). Whole communities can be easily sampled and used in experiments both in the field and in the laboratory. In $S$. purpurea's native range in North America, insects fall and drown in the trapped rainwater. Bacteria and yeast colonize the system, decompose the insects, and liberate nutrients for the plant. A variety of protists and a rotifer species also colonize this community and consume the bacteria. These species come from a larger pool of species that are present in the local habitat (e.g., Bledzki and Ellison 2003). The highest trophic level is composed of the larvae of the endemic pitcher plant mosquito, Wyeomyia smithii, which feed on the protists and rotifers. Numerous studies using the $S$. purpurea model system have been conducted in the native range of North America (e.g., Addicott 1974; Bradshaw and Holzapfel 2001; Kneitel and Miller 2002; Gotelli and Ellison 2006; Miller and terHorst 2012).

S. purpurea has been introduced by seed into Europe and therefore lacks its native resident aquatic community. In Switzerland, it was planted in several locations in the Jura Mountains and Alpine regions in the late nineteenth century (Correvon 1947), and in several sites at lower elevations in the 1950s (Parisod et al. 2005). This introduction has allowed for the development of parallel aquatic communities in North America and Europe, but with different evolutionary histories. In Europe, where the inquiline communities have had a shorter time period to adapt to the environment of the $S$. purpurea leaves and develop shared evolutionary trajectories, evidence has shown that there may be a larger number of protist species present than in North America [51 protist morphospecies plus 17 species of coccal green algae inside $S$. purpurea leaves in a single site in Germany (Gebühr et al. 2006) versus 48 morphospecies found across North America by Buckley et al. (2010)]. The species composition of the inquiline $S$. purpurea community across Europe may also be more heterogeneous than in North America since we found little overlap in composition with Gebühr et al. (2006) in our study involving only first-year pitchers. Most importantly, the W. smithii larvae of the $S$. purpurea system have experienced the inquiline prey community in North America for at least 10,000 years. On the contrary, the communities that developed in Europe have never experienced $W$. smithii as a top predator, and very likely have never experienced any insect top predator in the leaf (Gebühr et al. 2006; Fragnière 2012), making them top-predator-naive communities. This island-like freshwater system is therefore ideal for addressing questions about the effects of novel predators on natural, naive aquatic communities.

Here, we conducted a full-factorial common-garden experiment where we manipulated the presence/absence of the W. smithii top predator in natural communities (protists and bacteria) that did or did not share a habitat with the top predator and thus did or did not adapt avoidance or tolerance mechanisms against W. smithii. The non-naive communities come from two sites in Québec (Canada) and the naive ones come from two sites in Switzerland. Sites were chosen to match in climatic conditions and day length (similar latitude). Additionally, we tested the effect of the predator on early- and late-successional communities. First, we hypothesized that the predator-induced change in protist species composition should be stronger for naive communities because the species within $S$. purpurea leaves have not experienced W. smithii predation [naive prey hypothesis (Elton 1958; Diamond and Case 1986; Cox and Lima 2006; Freeman and Byers 2006)]. Second, early-succession communities, whose composition is typically dominated by small-bodied species allocating more energy to reproduction, should be more affected than late-succession communities that have been structured by predation and competition events (Clements 1916; Odum 1969; Kuno 1987; Louette et al. 2008; Kadowaki et al. 2012). Third, independent of community origin, the distribution of body size within a community should change due to preferential predation (Sommer et al. 1986; Wootton 1993; Hansson et al. 1998). Fourth, the effect of the top predator should cascade down to the bacterial trophic level because the bacteria will be released from the predation pressure of the protists (Kneitel and Miller 2002), an effect predicted to be strongest in early-succession and naive communities. Fifth, as a corollary, ecosystem functioning - measured as global respiration-should be highest in naive, early-succession communities because of a trophic cascade in the presence of a top predator [assuming that bacteria dominate in respiration (e.g., Simon et al. 1992; Gebühr et al. 2006)].

\section{Materials and methods}

We conducted a common-garden full-factorial experiment using communities from four sites, two successional stages per site, and two predator treatments (present $=$ two third-instar mosquito larvae, or absent $=$ no mosquito larvae). Each treatment was replicated four times for a total of 64 samples. We selected four climatically similar sites with regard to average July temperatures (averaged across 50 years, Worldclim data; www.worldclim.org). The sites also matched in day length due to their similar latitudes. Two of these sites were in the native range of $S$. purpurea in Québec (Lac des Joncs, 48 $29^{\prime} 61.00^{\prime \prime} \mathrm{N}, 68^{\circ} 77^{\prime} 15.55^{\prime \prime} \mathrm{W}$; Lac Rimouski, $48^{\circ} 18^{\prime} 32.71^{\prime \prime} \mathrm{N}, 68^{\circ} 28^{\prime} 14.68^{\prime \prime} \mathrm{W}$ ), where the species were not naive to the top predator. The other two sites were in Switzerland (Les Embreux, $47^{\circ} 15^{\prime} 45.82^{\prime \prime} \mathrm{N}$, $7^{\circ} 6^{\prime} 57.79^{\prime \prime} \mathrm{E}$; Les Tenasses, 46 $\left.29^{\prime} 28.51^{\prime \prime} \mathrm{N}, 6^{\circ} 55^{\prime} 16.04^{\prime \prime} \mathrm{E}\right)$, where the species were naive to the top predator. At each 
site, we marked randomly-selected leaves that were likely to open within several days. We returned to the sites 2 weeks later and marked a different set of leaves that were about to open. After 1 month since the first leaf markings, we returned to the field sites and collected water (the aquatic community) from all marked leaves. The aquatic communities that were collected from the 4-week-old leaves were designated as "late-succession communities" and the aquatic communities that were from 2-week-old leaves were designated as "early-succession communities". A 1-month duration is a reasonable interval for this community to reach late-succession because the community consists of bacteria and protists, which have fast generation times (Gray 2012). Note that early- and late-succession communities from Québec already experienced W. smithii predation at the time of sampling [W. smithii lay their eggs immediately after pitcher opening (Smith 1902)]. At each site, the communities of each successional time period were pooled and placed into sterilized containers. The samples were then cooled on ice packs and brought back to the laboratory, where they were sieved in order to remove large detritus pieces and, for Québec, invertebrate larvae in both early- and late-succession communities. Larvae were also removed by pipetting after careful visual inspection of each sample. Note that no Diptera larvae were found in the Swiss communities. All samples were chilled on ice to slow community dynamics until the start of the experiment (approximately $72 \mathrm{~h}$ later). The Swiss communities were transferred to North America under these constant conditions. Every visit to the four sites occurred on the same day, using a detailed protocol for marking, collecting, and storing samples.

On the same day that the experiment was started, fresh mosquito larvae were collected from $S$. purpurea water at the Lac de Joncs site. These larvae were brought back to the laboratory and placed into four replicate water baths for $30 \mathrm{~min}$ each. We measured bacterial cell density of each pooled community with a flow cytometer, standardized via dilution with sterilized deionized water. We then set up eight tubes for each successional stage at each site. We used $50-\mathrm{mL}$ sterilized macrocentrifuge tubes containing 2-mL autoclaved glass beads to mimic the insect exoskeletons and detritus naturally found at the bottom of $S$. purpurea pitchers (Gray et al. 2014). Each tube was wrapped with opaque paper until the $25-\mathrm{mL}$ mark to mimic the light availability present inside $S$. purpurea leaves. Using a sterilized pipette (one per treatment community), we transferred 20 -mL of $S$. purpurea water containing standardized bacterial density into each macrocentrifuge tube. We then allocated the eight tubes for each site and successional stage into two predator treatments, allowing for four replicates in the no-top-predator and four in the top-predator treatment. In the top-predator treatment, we placed two third-instar larvae of W. smithii, which corresponds approximately to average observed larval densities in mature leaves in northern latitudes (Nastase et al. 1995; Buckley et al. 2003; Hoekman 2007). One milliliter of sterilized fish food solution $(5.4 \mathrm{~g} / \mathrm{L})$ was added to all samples as a feeding source for the community to standardize the nutrient content. All tubes were placed in a randomized block design for 7 days in an incubator (Sanyo MIR-154), which was programmed to the 50-year average July temperatures of the four sites (Worldclim Data), varying from 10 to $21{ }^{\circ} \mathrm{C}$ over $24 \mathrm{~h}$ (average temperature $15.5{ }^{\circ} \mathrm{C}$ ), and natural light conditions. On every day of the experiment, we checked if the mosquito larvae had died or pupated. In such cases, we replaced the dead or pupating mosquito with a new thirdinstar larva that was collected at the same time and from the same site as the original mosquito. The spare larvae were stored under experimental conditions.

Measurements took place on days 0 and 6 (end). For day 0 (before the initiation of the experiment), we measured the initial protist composition and size spectra, and community respiration across all sites and successional stages. The same measurements, including changes in bacterial density, were taken on day 6. Bacterial density for each treatment was measured with a flow cytometer. Respiration of a 1-mL sample of each community was measured using the MicroResp TM system (James Hutton Institute, Scotland) according to the manufacturer's protocol (Carmen 2007). For the determination of protist community structure, an aliquot of $80 \mu \mathrm{L}$ of each community was used. Observations of presence/absence and size spectra for all protist species were obtained using a compound microscope, with magnification ranging between $\times 100$ and $\times 400$. Furthermore, pictures and videos of the protists were taken to facilitate recognition and determination of the morphospecies and their classification into size spectra. For all morphospecies encountered, we used the reference of Lee et al. (2000) for identification. Cell sizes ranging from ca. 3-5 $\mu \mathrm{m}$ for the smallest species up to $150 \mu \mathrm{m}$ for the largest species were measured using the pixel-counting feature of the program ImageJ (Rasband 2012). We assigned minimum and maximum cell size to each morphospecies according to Streble and Krauter (2002). Morphospecies were then classified into three size classes: small, $<8 \mu \mathrm{m}$; medium, $8-40 \mu \mathrm{m}$; large, 40-150 $\mu \mathrm{m}$. When dealing with colonies of protists, the size of a single cell was measured and the species were grouped into one of the three size classes accordingly. Note that we concentrated on species composition because it is already known that W. smithii has a strong effect on the abundance of protists (Addicott 1974; Hoekman 2007, 2010; Gray et al. 2014). Our choice was further motivated by the current interest in the impact of invaders on the diversity and species composition of resident communities (e.g., Hector et al. 2002; Fargione and Tilman 2005). 


\section{Statistical analyses}

The difference in protist community composition when a top predator was present or absent (hypotheses 1 and 2) was determined with non-metric multidimensional scaling for early- and late-succession among each of the four sites on days 0 and 6 (Legendre and Legendre 1998); nonmetric multidimensional scaling analyses were based on Jaccard distance matrices and performed using Primer 6.1 [version 6.1.6; Primer E 2006 (Clarke and Gorley 2006)]. We used two dimensions, which always resulted in stress values smaller than 0.08 . We also conducted an analysis of similarity and a multivariate dispersion analysis for these treatments. Analysis of similarity was used to measure the compositional distance between replicate communities with and without predators; the output of the method is a global $R$-value, which indicates significantly different communities when $R>0.5$. Multivariate dispersion provides an estimation of the dispersion of the replicates within each treatment; it computes an index of multivariate dispersion, a measure of the difference in dispersion between two treatments, where negative values indicate lower dispersion of communities with predators compared to communities without predators.

The effects of the top predator, successional stage, and naive/non-naive status of the community were evaluated with Gaussian generalized linear models on the following response variables: (1) the change between the start and the end of the experiment in protist species richness and body-size distribution of three body-size classes (hypothesis 3); (2) bacterial density (hypothesis 4); and (3) respiration (hypothesis 5) at the end of the experiment. All model residuals were checked for normality with quantile-quantile plots; no data transformation was necessary. For each analysis, we performed a model selection and we present the results for the model that yielded the lowest Akaike information criterion value. Due to small sample size, we further checked our results with the corrected Akaike information criterion; we found no difference in model selection based on both criteria. Analyses were performed in $\mathrm{R}(\mathrm{R}$ Core Team 2013).

\section{Results}

\section{Protist community composition}

The presence of the top predator significantly affected protist community composition at the end of the experiment, but only when the community was naive to top predators and at an early stage of succession (Fig. 1; Table 1). Dispersion tests yielded significant values for these naive, early-succession communities (early Les Embreux and early Les Tenasses;

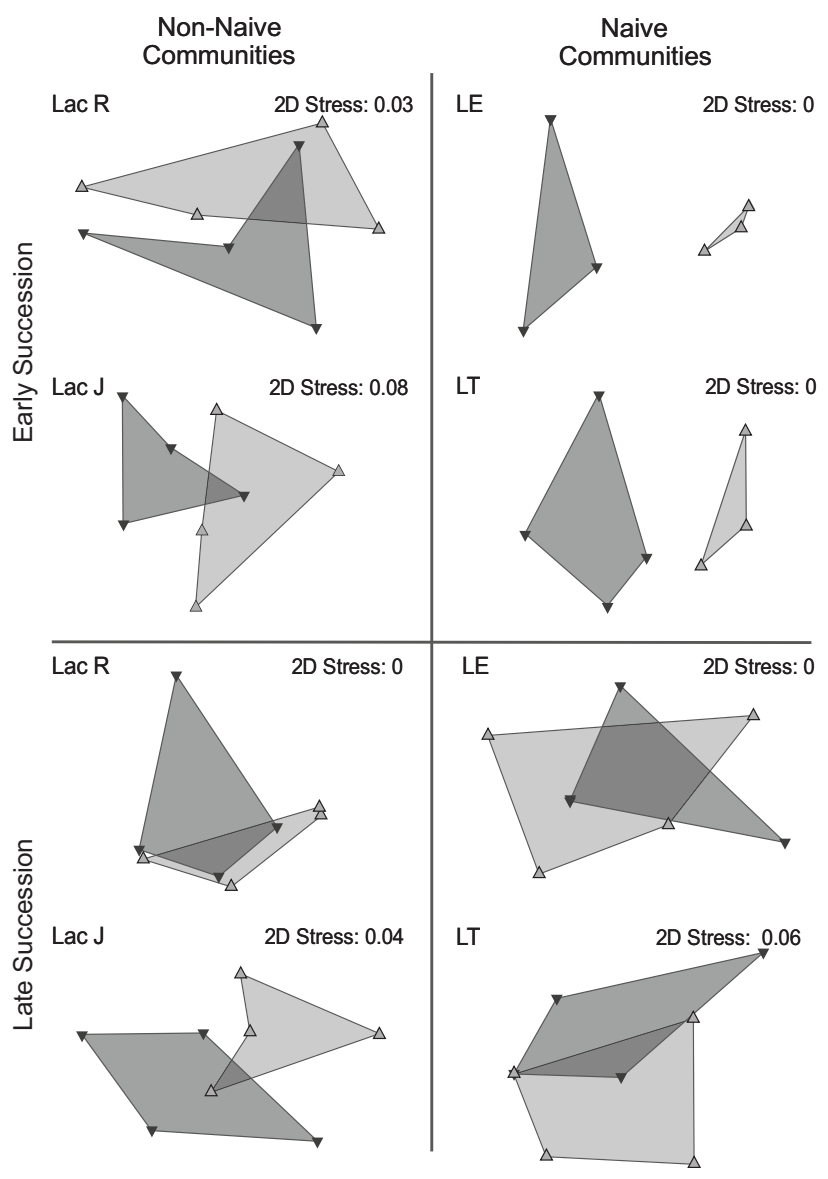

Fig. 1 Change in protist community composition. Each triangle represents one community in a two-dimensional (2D) non-metric multidimensional scaling plot [predator present (gray triangle and lightgray shading ( $n=8$ for each sampling site $/ n=32$ in total); predator absent (black inverted triangle and dark-gray shading $(n=8$ for each sampling site $/ n=32$ in total)]. Nearby triangles have similar species composition [in the case of identical community composition, the symbols representing these communities completely overlap; see Les Embreux (LE) and Les Tenasses (LT) early-succession]. The shaded envelopes were added to help visualize: (1) the amount of community composition overlap that occurred between the predator/no predator treatments, and (2) how similar community composition was within a treatment (the smaller the shaded area, the more similar the communities are to each other). The presence of the top predator only significantly changed protist composition in naive, early communities (see Table 1). LacR Lac Rimouski, LacJ Lac des Joncs, LE Les Embreux, LT Les Tenasses

see Table 1). Interestingly, when the predator was present, the four replicated early-succession communities were very similar in composition within the two naive sites. It therefore appears that the presence of a top predator results in the composition of naive, early-succession communities converging in similarity (strongly negative values for index of multivariate dispersion in both groups; see Table 1). The composition of the non-naive communities and of all late-succession communities was not affected by the presence of a top predator. 
Table 1 Results of analyses of similarity (ANOSIM) and multivariate dispersion (MVDISP) for the naive and non-naive communities, in earlyand late-succession

\begin{tabular}{lllllll}
\hline Succession & Site & Global $R$ & $p$-value & MVDISP with predator & MVDISP without predator & IMD value \\
\hline Early & Non-naive (LacR) & -0.302 & 0.943 & 1.051 & 0.949 & 0.111 \\
Early & Non-naive (LacJ) & -0.089 & 0.629 & 1.231 & 0.769 & 0.5 \\
Early $^{\text {a }}$ & Naive (LT) & $\mathbf{0 . 4 7 4}$ & $\mathbf{0 . 0 2 9}$ & $\mathbf{0 . 7 8 2}$ & $\mathbf{1 . 2 1 8}$ & $\mathbf{- 0 . 4 7 2}$ \\
Early $^{\mathrm{a}}$ & Naive (LE) & $\mathbf{0 . 8 5 4}$ & $\mathbf{0 . 0 2 9}$ & $\mathbf{0 . 7 6 9}$ & $\mathbf{1 . 2 3 1}$ & $\mathbf{- 0 . 5}$ \\
Late $_{\text {ate }}$ & Non-naive (LacR) & -0.036 & 0.686 & 0.923 & 1.077 & -0.167 \\
Late & Non-naive (LacJ) & 0.177 & 0.171 & 0.859 & 1.141 & -0.306 \\
Late & Naive (LT) & -0.115 & 0.857 & 1.013 & 0.987 & 0.028 \\
\hline
\end{tabular}

ANOSIM measures the compositional distance between communities with and without predators. A global $R$-value $>0.5$ indicates biologically significantly different communities. MVDISP provides an estimation of the dispersion of the replicates within each treatment; index of multivariate dispersion $(I M D)$ is a measure of the difference in dispersion between the two predation treatments; negative values indicate lower dispersion of communities with predators compared to the communities without predator

Non-naive Québec sites [Lac Rimouski (LacR) and Lac de Joncs (LacJ)], Naive Swiss sites [Les Tenasses (LT) and Les Embreux (LE)]

${ }^{\text {a }}$ Early naive sites with boldface type indicating a global $R$ value approximately equal or larger than 0.5

\section{Change through time of protist community structure}

The change in protist morphospecies richness from the beginning to the end of the experiment ( $\Delta$ species richness) was independent of the presence of the top predator (Fig. S1a Supplemental Material). However, the change in species composition, measured as Jaccard distance over time, was affected by the presence of top predators. This change was particularly strong in early-succession (Fig. 2a) and in naive (Fig. 2b) communities, where communities containing a top predator became significantly different in protist composition compared to communities with no top predator. Globally, the top-predator-induced change in species composition was driven by nine out of 36 morphospecies, all of which belonged to the small- and medium-size classes. Four morphospecies were negatively affected, but interestingly this number was counterbalanced by five species that increased in occurrence in the treatments that contained top predators (see Fig. S2).

Species composition differed among sites and successional stage at the start of the experiment (Fig. S3). Although the compositions were different, there was generally an equal number of small- and medium-sized protists within early- and late-succession communities (naive and non-naive communities pooled); however, there were less large-sized protists in early-successional than late-successional communities (see legend of Fig. S3; Table S1 for details). At the end of experiment, the presence/absence of the predator had no statistically significant effect on the total number of morphospecies (Fig. S1a), or on the number of morphospecies in the three different size classes (all $p$-values $>0.33$ ). Only naivety status had a detectable influence for the medium-size class (Fig. S1b), in which

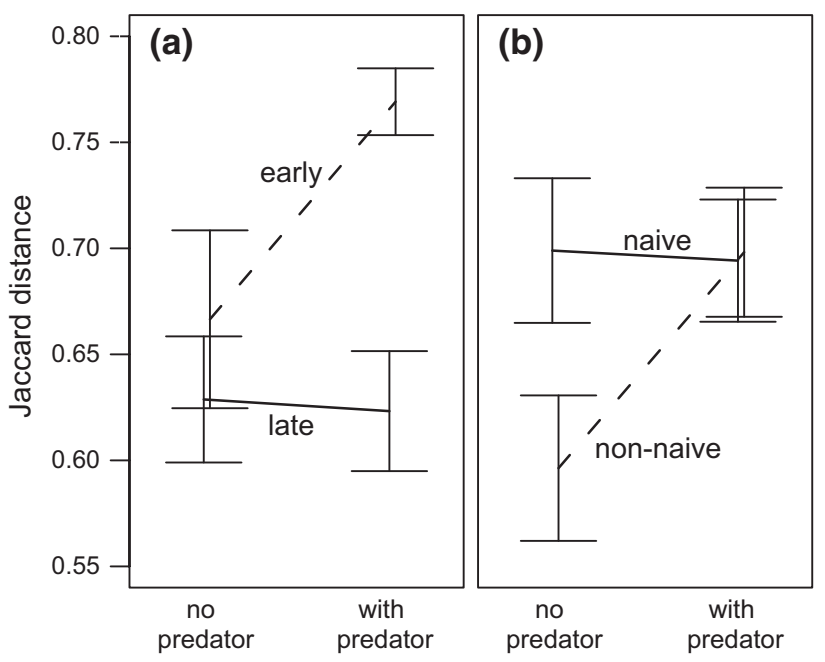

Fig. 2 Effect of succession, naivety status and top predator on protist community composition. Interaction plots for the distance in community composition (measured by Jaccard index comparing communities at the beginning and at the end of the experiment) for a early- (dashed line; $n=32$ ) and late-succession (solid line; $n=32$ ) communities, and $\mathbf{b}$ for naive (dashed line; $n=32$ ) and non-naive (solid line; $n=32$ ) communities, with and without the top predator. Error bars represent \pm 1 SE. Results of a Gaussian generalized linear model yield a significant effect for the presence of the top predator ( parameter $=0.16, p$-value $=0.003$ ), and naivety status (parameter $=0.10, p$-value $=0.017)$, but not of the successional stage (parameter $=-0.04, p$-value $=0.367$ )

there was a net loss of medium-sized species during the experiment for communities originating from Switzerland (naive), and a small gain in medium-sized species for communities originating from Québec (non-naive). There was also a marginally significant effect of succession and of 
the interaction between origin and succession for mediumsized species.

\section{Trophic regulation and ecosystem functioning}

The effect of the top predator did not propagate to the bottom trophic level. There, the top-predator effect on bacterial density was statistically insignificant in both naive and non-naive communities ( $p$-value $=0.119$ ) and in early- and late-succession ( $p$-value $=0.547$; see Table S2 for details). This lack of a statistically significant effect on bacterial density was consistent with the results for bacterial respiration: we found that the top predator had no impact on respiration rate in naive and non-naive $(p$-value $=0.32)$ and in early and late communities ( $p$-value $=0.61$; see Table S4 for details). Instead, the only significant result was that non-naive communities respire less than naive ones ( $p=0.038$; Fig. S4a and see Table S3 for details). We also found a significant interaction between succession and naivety, in which respiration increases when communities transition from early- to late-succession in naive communities, but decreases in non-naive communities ( $p=0.041$; Fig. S4b and Table S3).

\section{Discussion}

We found that the composition of early-succession Swiss (naive) protist communities diverged significantly from communities with no top predator present. This result supports our first (naivety status) and second (successional stage) hypotheses, but only in the naive, earlysuccession treatment, where we had expected the strongest effect. Indeed, there was no evidence of a difference in protist composition induced by the predator between early- and late-succession for non-naive communities. This result can be explained simply by the fact that earlysuccessional communities in Québec had already experienced the presence of W. smithii, and thus went through the biotic filter imposed by the predator. Indeed, $W$. smithii lay eggs in pitchers directly after they open (Smith 1902; Istock et al. 1975), so that protists experience predation early during community development. In the nonnaive range, only species tolerant to $W$. smithii were likely to survive in the pitchers until sampling for the experiment took place.

Interestingly, we also found no evidence of a change for late-succession communities in the naive sites, suggesting that the filtering process of succession in the $S$. purpurea leaves selects species that are not only competitively superior, but also resistant to predation. We further found that the presence of a top predator did not change the size distribution of protist species, as was predicted.
Surprisingly, the effect on species composition did not propagate to the bottom trophic level, as found for freshwater systems (e.g., Shurin et al. 2002), nor did it affect ecosystem functioning. Overall, our results highlight the importance of considering the successional stage of communities, which is rarely discussed as having a large impact on invasion at the multi-trophic level. For example, in the extensive review on invasion research by Lowry et al. (2013), successional stage was not used as a criterion to classify the surveyed studies.

In Europe, where $S$. purpurea was recently introduced, the inquiline species had to make a transition from the bog habitat to that of leaves. Only a subset of species has made this transition (Gebühr et al. 2006; Fragnière 2012), and these species had neither co-evolved with the plant, nor had they experienced W. smithii predation. Every year when new leaves open, pioneer species randomly colonize and pass through the environmental filter imposed by the leaf habitat (e.g., air barrier to other aquatic habitats, high variability in temperature, $\mathrm{pH}$ and nutrients inside the leaf). Priority effects imposed by the already established inquiline species can then limit those arriving later (e.g., Kadowaki et al. 2012). These "neutral" factors are probably paramount for the organization of these early communities. Interestingly, in these naive, early-succession communities, in addition to the compositional change induced by the predator, we observed a strong convergence in morphospecies identity. This suggests the importance of predators in constraining the trajectories of community assembly in systems that are naive to predation.

We also hypothesized that the European late-succession communities should be affected by insect predation because they did not have time to develop strategies to cope with consumers, and thus vary in their response to predation. However, our results do not support this hypothesis, suggesting that protist species were equally tolerant to $W$. smithii in this successional stage. Since we did not observe a change in respiration and bacterial density between European and Canadian late-succession communities when a predator was present, naive communities appear to be as resistant to predation as non-naive ones. This result underlies the hypothesis that mechanisms of avoidance/tolerance against one predator are also effective against other similar types of filter-feeding predators (Anson and Dickman 2013).

Our results are consistent with other $S$. purpurea studies conducted in northern latitudes. From field experiments performed in Michigan (non-naive, native range, with a similar temperature range as our experiment), Hoekman (2007, 2010) found that, although protozoan biovolume greatly decreased in the presence of the mosquito top predator, bacterial density was unaffected. Further, Hoekman (2007) found that the species richness of non-naive prey 
communities was affected, but only when 20 mosquito larvae were added to the system, which corresponds to high mosquito density in a natural setting (Nastase et al. 1995). It is likely the top predator would have affected the species richness of the non-naive communities in our study if more larvae had been added to the system (20 larvae vs. two larvae per community). Our results imply that the addition of only two mosquito larvae is sufficient to affect naive, earlysuccession communities. In this respect, the changes in the occurrence of species can be directly caused by predation, but also indirectly by a competition/predation trade-off favoring less-competitive species (Kneitel 2012).

We used a whole community (bacteria and protists) microcosm system to answer a question of general importance for conservation biology that is especially relevant at the ecosystem level. Simplified versions of larger-scale communities can provide tractability and high statistical power (Srivastava et al. 2004), allowing us to better understand what mechanisms may drive dynamics in more complex systems (Jessup et al. 2004). In this respect, we want to emphasize the importance of working with natural communities, where species have adapted to each other, so that they are more likely to epitomize larger-scale systems. Furthermore, our system is microbial, species of which are likely to evolve quite rapidly (Jessup et al. 2004). This characteristic of microbial systems makes it possible that the naive, early-successional communities in our study could have become more tolerant of the top predator if the experiment had been longer. The fact that the protist species were still vulnerable after 6 days suggests that largerscale systems may take a long time to adjust to environmental changes. Our results also point to the importance of working with different successional stages. The observed effects of the top predator are subtle in our case, affecting only early-succession communities. Human activities such as deforestation and intensive agriculture reset many habitats worldwide to an early-successional stage. Since the effects of novel predators appear to be dependent on the successional stage (e.g., Estes et al. 2011), it is therefore necessary that conservation research consider information about the succession of the ecosystem.

Acknowledgments We would like to thank Steve Vissault, Renaud McKinnon, Timothée Poisot, Génika Hulliger, Marie-Amélie Girardet, and Elodie Parain for their aid in marking leaves, collecting samples, and in laboratory preparation. Funding sources for this project are the Swiss National Science Foundation Grant awarded to L. F. B. (31003A_138489), the SNSF International Short Visit Grant awarded to S. M. G., and the NSERC-Discovery Grant awarded to D. G.

Author contribution statement All authors designed the research; A. Z. and S. M. G. conducted the research; A. Z., L. F. B. and S. M. G. wrote the manuscript; all authors edited the manuscript; D. G., L. F. B. and S. M. G. funded the project.

\section{References}

Addicott JF (1974) Predation and prey community structure: an experimental study of the effect of mosquito larvae on the protozoan communities of pitcher plants. Ecology 55:475-492. doi: $10.2307 / 1935141$

Anson J, Dickman C (2013) Behavioral responses of native prey to disparate predators: naiveté and predator recognition. Oecologia 171(367a):171. doi:10.1007/s00442-012-2424-7

Baxter CV, Fausch KD, Murakami M, Chapman PL (2004) Fish invasion restructures stream and forest food webs by interrupting reciprocal prey subsidies. Ecology 85:2656-2663. doi:10.1890/04-138

Belyea LR, Lancaster J (1999) Assembly rules within a contingent ecology. Oikos 86:402-416

Bledzki LA, Ellison AM (2003) Diversity of rotifers from northeastern USA bogs with new species records for North America and New England. Hydrobiologia 497:53-62

Bradshaw WE, Holzapfel CM (2001) Genetic shift in photoperiodic response correlated with global warming. Proc Natl Acad Sci USA 98:14509-14511. doi:10.1073/pnas.241391498

Bruno JF, Fridley JD, Bromberg K, Bertness MD (2005) Insights into biotic interactions from studies of species invasions. In: Sax DF, Gaines SD, Stachowicz JJ (eds) Species invasions: insights into ecology, evolution and biogeography. Sinauer, Sunderland, pp 13-40

Buckley HL, Miller TE, Ellison AM, Gotelli NJ (2003) Reverse latitudinal trends in species richness of pitcher plant food webs. Ecol Lett 6:825-829. doi:10.1046/j.1461-0248.2003.00504.x

Buckley HL, Miller TE, Ellison AM, Gotelli NJ (2010) Local- to continental-scale variation in the richness and composition of an aquatic food web. Glob Ecol Biogeogr 19:711-723. doi:10.1111/j.1466-8238.2010.00554.x

Carmen C (2007) MicroResp technical manual-a versatile soil respiration system. Macaulay Institute, Aberdeen

Carpenter SR, Kitchell JF, Hodgson JR (1985) Cascading trophic interactions and lake productivity. Bioscience 35:634-639. doi:10.2307/1309989

Catford JA, Daehler CC, Murphy HT, Sheppard AW, Hardesty BD, Westcott DA, Rejmánek M, Bellingham PJ, Pergl J, Horvitz CC, Hulme PE (2012) The intermediate disturbance hypothesis and plant invasions: implications for species richness and management. Perspect Plant Ecol Evol Syst 14:231-241. doi:10.1016/j. ppees.2011.12.002

Clarke KR, Gorley RN (2006) PRIMER v6: user manual/tutorial. PRIMER-E, Plymouth

Clements FE (1916) Plant succession; an analysis of the development of vegetation. Carnegie Institution of Washington, Washington

Connell JH, Slatyer RO (1977) Mechanisms of succession in natural communities and their role in community stability and organization. Am Nat 111:1119-1144. doi:10.2307/2460259

Correvon H (1947) Fleurs des eaux et des marais. Delachaux et Niestlé, Neuchâtel

Courchamp F, Chapuis J-L, Pascal M (2003) Mammal invaders on islands: impact, control and control impact. Biol Rev 78:347383. doi:10.1017/S1464793102006061

Cox JG, Lima SL (2006) Naiveté and an aquatic-terrestrial dichotomy in the effects of introduced predators. Trends Ecol Evol 21:674680. doi:10.1016/j.tree.2006.07.011

del Moral R, Wood DM (1993) Early primary succession on the volcano Mount St. Helens. J Veg Sci 4:223-234. doi: $10.2307 / 3236108$

Diamond J, Case TJ (1986) Overview: Introductions, extinctions, exterminations, and invasions. In: Diamond J, Case TJ (eds) Community ecology. Harper and Row, London, pp 65-79 
Dickman CR (1996) Impact of exotic generalist predators on the native fauna of Australia. Wildl Biol 2:185-195

Elton CS (1958) The ecology of invasions by animals and plants. Methuen, London

Estes JA, Terborgh J, Brashares JS, Power ME, Berger J, Bond WJ, Carpenter SR, Essington TE, Holt RD, Jackson JBC, Marquis RJ, Oksanen L, OksanenT Paine RT, Pikitch EK, Ripple WJ, Sandin SA, Scheffer M, Schoener TW, Shurin JB, Sinclair RE, Soulé ME, Virtanen R, Wardle DA (2011) Trophic downgrading of planet earth. Science 333:301-306. doi:10.1126/ science. 1205106

Fabian Y, Sandau N, Bruggisser OT, Kehrli P, Aebi A, Rohr RP, Naisbit RE, Bersier LF (2012) Diversity protects plant communities against generalist molluscan herbivores. Ecol Evol 2:2460-2473. doi:10.1002/ece 3.359

Fargione JE, Tilman D (2005) Diversity decreases invasion via both sampling and complementarity effects. Ecol Lett 8:604-611. doi:10.1111/j.1461-0248.2005.00753.x

Foster BL, Tilman D (2000) Dynamic and static views of succession: testing the descriptive power of the chronosequence approach. Plant Ecol 146:1-10

Fragnière Y (2012) Colonisation of Sarracenia purpurea pitchers in Swiss populations. Master thesis, Unit of Ecology and Evolution, University of Fribourg, Fribourg, Switzerland

Freeman AS, Byers JE (2006) Divergent induced responses to an invasive predator in marine mussel populations. Science 313:831-833

Gebühr C, Pohlon E, Schmidt AR, Küsel K (2006) Development of microalgae communities in the phytotelmata of allochthonous populations of Sarracenia purpurea (Sarraceniaceae). Plant Biol 8:849-860. doi:10.1055/s-2006-924474

Gleason HA (1926) The individualistic concept of the plant association. Bull Torrey Bot Club 53:7. doi:10.2307/2479933

Goldschmidt T, Witte F, Wanink J (1993) Cascading effects of the introduced nile perch on the detritivorous/phytoplanktivorous species in the sublittoral areas of Lake Victoria. Conserv Biol 7:686-700. doi:10.1046/j.1523-1739.1993.07030686.x

Gotelli NJ, Ellison AM (2006) Food-web models predict species abundances in response to habitat change. PLoS Biol 4:e324

Gray SM (2012) Succession in the aquatic Sarracenia purpurea community: deterministic or driven by contingency? Aquat Ecol 46:487-499. doi:10.1007/s10452-012-9417-9

Gray SM, Miller TE, Mouquet N, Daufresne T (2006) Nutrient limitation in detritus-based microcosms in Sarracenia purpurea. Hydrobiologia 573:173-181. doi:10.1007/s10750-006-0265-2

Gray SM, Dykhuizen DE, Padilla DK (2014) The effects of species properties and community context on establishment success. Oikos. doi:10.1111/oik.01550

Gurevitch J, Padilla DK (2004) Are invasive species a major cause of extinctions? Trends Ecol Evol 19:470-474

Hairston NG, Smith FE, Slobodkin LB (1960) Community structure, population control, and competition. Am Nat 94:421-425. doi: $10.2307 / 2458808$

Hansson L-A, Bergman E, Cronberg G (1998) Size structure and succession in phytoplankton communities: the impact of interactions between herbivory and predation. Oikos 81:337-345. doi: $10.2307 / 3547054$

Heard SB (1994) Pitcher-plant midges and mosquitoes: a processing chain commensalism. Ecology 75:1647-1660. doi: $10.2307 / 1939625$

Hector A, Dobson K, Minns A, Bazeley-White E, Lawton JH (2002) Community diversity and invasion resistance: an experimental test in a grassland ecosystem and a review of comparable studies. Ecol Res 16:819-831. doi:10.1046/j.1440-1703.2001.00443.x

Hoekman D (2007) Top-down and bottom-up regulation in a detritusbased aquatic food web: a repeated field experiment using the pitcher plant (Sarracenia purpurea) inquiline community. Am Midl Nat 157:52-62. doi:10.1674/0003-0031(2007)157[52:TAB RIA]2.0.CO;2

Hoekman D (2010) Turning up the heat: temperature influences the relative importance of top-down and bottom-up effects. Ecology 91:2819-2825. doi:10.1890/10-0260.1

Hunter MD, Price PW (1992) Playing chutes and ladders: heterogeneity and the relative roles of bottom-up and top-down forces in natural communities. Ecology 73:723-732

Hutchinson GE (1961) The paradox of the plankton. Am Nat 95:137145. doi: $10.2307 / 2458386$

Istock CA, Wasserman SS, Zimmer H (1975) Ecology and evolution of the pitcher-plant mosquito: 1. population dynamics and laboratory responses to food and population density. Evolution 29:296-312. doi:10.2307/2407218

Jessup CM, Kassen R, Forde SE, Kerr B, Buckling A, Rainey PB, Bohannan BJ (2004) Big questions, small worlds: microbial model systems in ecology. Trends Ecol Evol 19:189-197. doi:10.1016/j.tree.2004.01.008

Jiang L, Joshi H, Flakes SK, Jung Y (2011) Alternative community compositional and dynamical states: the dual consequences of assembly history. J Anim Ecol 80:577-585. doi:10.1111/j.1365-2656.2010.01799.x

Kadowaki K, Inouye BD, Miller TE (2012) Assembly-history dynamics of a pitcher-plant protozoan community in experimental microcosms. PLoS One 7:e42651. doi:10.1371/journal. pone. 0042651

Kneitel JM (2012) Are trade-offs among species' ecological interactions scale dependent? A test using pitcher-plant inquiline species. PLoS One 7:e41809. doi:10.1371/journal.pone.0041809

Kneitel JM, Miller TE (2002) Resource and top-predator regulation in the pitcher plant (Sarracenia purpurea) inquiline community. Ecology 83:680-688. doi:10.1890/0012-9658(2002)083[0680:RATPRI]2.0.CO;2

Kuno E (1987) Principles of predator-prey interaction in theoretical, experimental, and natural population systems. In: Macfadyen A, Ford ED (eds) Advances in ecological research. Academic Press, San Diego, pp 249-337

Lee JJ, Leedale GF, Bradbury P (2000) An illustrated guide to the protozoa, 2nd edn. Society of Protozoologists, Lawrence

Legendre P, Legendre L (1998) Numerical ecology, 2nd English edn. Elsevier Science, Amsterdam

Lortie CJ, Brooker RW, Choler P, Kikvidze Z, Michalet R, Pugnaire FI, Callaway RM (2004) Rethinking plant community theory. Oikos 107(4337):433. doi:10.1111/j.0030-1299.2004.13250.x

Louette G, De Meester L, Declerck S (2008) Assembly of zooplankton communities in newly created ponds. Freshwater Biol 53:2309-2320. doi:10.1111/j.1365-2427.2008.02052.x

Lowry E, Rollinson EJ, Laybourn AJ, Scott TE, Aiello-Lammens ME, Gray SM, Mickley J, Gurevitch J (2013) Biological invasions: a field synopsis, systematic review, and database of the literature. Ecol Evol 3:182-196. doi:10.1002/ece3.431

Manchester SJ, Bullock JM (2000) The impacts of non-native species on UK biodiversity and the effectiveness of control. J Appl Ecol 37:845-864. doi:10.1046/j.1365-2664.2000.00538.x

Miller TE, Kneitel JM (2005) Inquiline communities in pitcher plants as prototypical metacommunities. In: Holyoak M, Leibold MA, Holt RD (eds) Metacommunities: spatial dynamics and ecological communities. University of Chicago, Chicago, pp 122-145

Miller TE, terHorst C (2012) Testing successional hypotheses of stability, heterogeneity, and diversity in pitcher-plant inquiline communities. Oecologia 170:243-251. doi:10.1007/ s00442-012-2292-1

Miller TE, Kneitel JM, Burns JH (2002) Effect of community structure on invasion success and rate. Ecology 83:898-905. doi:10.1890/0012-9658(2002)083[0898:EOCSOI]2.0.CO;2 
Mortensen HS, Dupont YL, Olesen JM (2008) A snake in paradise: disturbance of plant reproduction following extirpation of bird flower-visitors on Guam. Biol Conserv 141:2146-2154. doi:10.1016/j.biocon.2008.06.014

Moyle PB (1986) Fish introductions into North America: patterns and ecological impact. In: Mooney H, Drake J (eds) Ecology of biological invasions of North America and Hawaii. Springer, New York, pp 27-43

Nastase AJ, Rosa CDL, Newell SJ (1995) Abundance of pitcher-plant mosquitoes, Wyeomyia smithii (Coq.) (Diptera: Culicidae) and midges, Metriocnemus knabi Coq. (Diptera: Chironomidae), in relation to pitcher characteristics of Sarracenia purpurea L. Am Midl Nat 133:44-51. doi:10.2307/2426346

Oakley CA, Knox JS (2013) Plant species richness increases resistance to invasion by non-resident plant species during grassland restoration. Appl Veg Sci 16:21-28. doi:10.1111/j.1654-109X.2012.01202.x

Odum EP (1969) The strategy of ecosystem development. Science 164:262-270. doi:10.1126/science.164.3877.262

Paolucci EM, MacIsaac HJ, Ricciardi A (2013) Origin matters: alien consumers inflict greater damage on prey populations than do native consumers. Divers Distrib 19:988-995. doi:10.1111/ ddi. 12073

Parisod C, Trippi C, Galland N (2005) Genetic variability and founder effect in the pitcher plant Sarracenia purpurea (Sarraceniaceae) in populations introduced into Switzerland: from inbreeding to invasion. Ann Bot 95:277-286. doi:10.1093/aob/mci023

Pianka ER (1970) On $r$ - and $K$-selection. Am Nat 104:592-597. doi: $10.2307 / 2459020$

Pomati F, Kraft NJB, Posch T et al (2013) Individual cell based traits obtained by scanning flow-cytometry show selection by biotic and abiotic environmental factors during a phytoplankton spring bloom. PLoS One 8:e71677. doi:10.1371/journal.pone.0071677

R Core Team (2013) R: a language and environment for statistical computing. Version 3.0.0. R Foundation for Statistical Computing, Vienna. http://www.R-project.org/

Rasband WS (2012) ImageJ. US National Institutes of Health, Bethesda, USA. imagej.nih.gov/ij/

Rees M, Condit R, Crawley M et al (2001) Long-term studies of vegetation dynamics. Science 293:650-655. doi:10.1126/ science. 1062586

Rodriguez L (2006) Can invasive species facilitate native species? Evidence of how, when, and why these impacts occur. Biol Invasions 8:927-939. doi:10.1007/s10530-005-5103-3

Salo P, Korpimäki E, Banks PB et al (2007) Alien predators are more dangerous than native predators to prey populations. Proc R Soc Lond B Biol Sci 274:1237-1243. doi:10.1098/rspb.2006.0444
Savidge JA (1984) Guam: paradise lost for wildlife. Biol Conserv 30:305-317. doi:10.1016/0006-3207(84)90049-1

Savidge JA (1987) Extinction of an island forest avifauna by an introduced snake. Ecology 68:660-668. doi:10.2307/1938471

Schmitz OJ, Kalies EL, Booth MG (2006) Alternative dynamic regimes and trophic control of plant succession. Ecosystems 9:659-672

Shurin JB, Borer ET, Seabloom EW, Anderson K, Blanchette CA, Broitman B, Cooper SD, Halpern BS (2002) A cross-ecosystem comparison of the strength of trophic cascades. Ecol Lett 5:785791. doi:10.1046/j.1461-0248.2002.00381.x

Sih A, Bolnick DI, Luttbeg B, Orrock JL, Peacor SD, Pintor LM, Preisser E, Rehage JS, Vonesh JR (2010) Predator-prey naïveté, antipredator behavior, and the ecology of predator invasions. Oikos 119:610-621. doi:10.1111/j.1600-0706.2009.18039.x

Simon M, Cho B, Azam F (1992) Significance of bacterial biomass in lakes and the ocean: comparison to phytoplankton biomass and biogeochemical implications. Mar Ecol Prog Ser 86:103-110

Smith JB (1902) Life-history of Aëdes smithii Coq. J NY Entomol Soc 10:10-15. doi:10.2307/25002970

Sommer U, Gliwicz ZM, Lampert W, Duncan A (1986) The PEGmodel of seasonal succession of planktonic events in fresh waters. Arch Hydrobiol 106:433-471

Sousa WP (1979) Experimental investigations of disturbance and ecological succession in a rocky intertidal algal community. Ecol Monogr 49:227-254. doi:10.2307/1942484

Srivastava DS, Kolasa J, Bengtsson J, Gonzalez A, Lawler SP, Miller TE, Munguia P, Romanuk T, Schneider DC, Trzcinski MK (2004) Are natural microcosms useful model systems for ecology? Trends Ecol Evol 19:379-384. doi:10.1016/j. tree.2004.04.010

Streble H, Krauter D (2002) Das Leben im Wassertropfen: Mikroflora und Mikrofauna des Süßwassersm, 9th edn. Kosmos (FranckhKosmos), Stuttgart

Walls M, Kortelainen I, Sarvala J (1990) Prey responses to fish predation in freshwater communities. Ann Zool Fenn 27:183-199. doi: $10.2307 / 23736038$

Wiles GJ, Bart J, Beck RE, Aguon CF (2003) Impacts of the brown tree snake: patterns of decline and species persistence in Guam's avifauna. Conserv Biol 17:1350-1360. doi:10.1046/j.1523-1739.2003.01526.x

Wootton JT (1993) Size-dependent competition: effects on the dynamics vs. the end point of mussel bed succession. Ecology 74:195-206. doi:10.2307/1939514 